\title{
Konsep Rasionalitas Islami dan Implikasinya terhadap Pengembangan Studi Ekonomi Islam
}

\author{
A. Dimyati \\ Institut Pesantren Mathali'ul Falah Pati \\ Email Korespondensi: dimyati@ipmafa.ac.id
}

\begin{abstract}
The study of Islamic rationality is the starting point for the theorizing of Islamic economics. Based on this concept, this article aims to elaborate rationality based on the concepts of classical Islamic thinkers, such as alGazali, Ibn Khaldun, Ibn Miskawaih and al-Mawardi. Through a search of their writings, the author intends to reconstruct the original concept of rationality from Islam. Then with the approach used by economic critics, the concept of rationality was expanded. The results of this study indicate that the rigidity of the concept of rationality in the Neoclassical school is undeniable. The behavior of actors in the economy is not only repetitive actions that can be quantified, but must be extended as part of the social system. Especially in the concept of Islamic rationality, economic behavior is also closely related to the position of humans as servants of Allah so that they have a spiritual dimension.
\end{abstract}

Keywords: Islamic rationality, Islamic Economics,

\begin{abstract}
Abstrak
Kajian tentang rasionalitas Islam merupakan titik tolak bagi teorisasi ekonomi Islam. Berdasarkan konsep tersebut, artikel ini bertujuan untuk mengelaborasi rasionalitas berdasarkan konsep-konsep pemikir Islam klasik, seperti al-Gazali, Ibn Khaldun, Ibn Miskawaih dan al-Mawardi. Melalui penelusuran tulisan-tulisan mereka, penulis bermaksud merekonstruksi konsep rasionalitas yang asli dari Islam. Kemudian dengan pendekatan yang digunakan oleh para kritikus ekonomi, konsep rasionalitas diperluas. Hasil penelitian ini menunjukkan bahwa kekakuan konsep rasionalitas dalam aliran Neoklasik tidak dapat disangkal. Perilaku para pelaku ekonomi bukan hanya tindakan berulang yang dapat dikuantifikasi tetapi harus diperluas sebagai bagian dari sistem sosial. Khususnya dalam konsep rasionalitas Islam, perilaku ekonomi juga erat kaitannya dengan kedudukan manusia sebagai hamba Allah sehingga memiliki dimensi spiritual.
\end{abstract}

Kata Kunci: Rasionalitas Islami, Ekonomi Islam

\section{A. Pendahuluan}

Studi Ekonomi Islam selama ini mengikuti arus utama yang menempatkan manusia sebagai makhluk rasional. Pemikiran ini bertolak dari rumusan kriteria ilmiah ala Positivisme yang mengharuskan setiap ilmu harus memiliki kemampuan melakukan 
Konsep Rasionalitas Islami dan Implikasinya ...

prediksi $^{1}$ dan eksplanasi ${ }^{2}$ terhadap berbagai kemungkinan yang terjadi (oleh Cal Hempel dan Peter Oppenheim, sebagaimana dikutip Agus Sugiyono, disebut logika simetri logical symmetry). Logika simetri ini mendapat banyak kritikan, yaitu bahwa prediksi tidak harus berimplikasi pada penjelasan dan sebaliknya. Sedangkan kemampuan eksplanasi digunakan untuk menerangkan kejadian alam maupun masyarakat yang telah terjadi. ${ }^{3} \mathrm{Pada}$ gilirannya, kepentingan ilmu ekonomi untuk melakukan prediksi secara akurat membawa pada pilihan untuk menarik hipotesis melalui penggunaan model-model kuantifikasi dan analisis matematik.

Adanya kecenderungan kuantifikasi ilmu ekonomi tidak terlepas dari cara pandang ilmu ekonomi terhadap perilaku manusia sehingga ia juga disebut sebagai ilmu perilaku (behavior science). Dalam perspektif ilmu ekonomi, perilaku manusia diasumsikan sepenuhnya rasional. Problemnya, kriteria rasional dibatasi dengan dua hal, pemenuhan kepentingan pribadi (self interest) dan memaksimalkan manfaat atau nlai guna (maximization of utility). Baik kepentingan pribadi maupun nilai guna didasarkan kalkulasi-kalkulasi biaya. Seseorang dianggap rasional jika biaya yang dikeluarkan lebih sedikit daripada nilai guna yang diterima. ${ }^{4}$

Faktanya, perilaku manusia tidak selalu sejalan dengan kriteria rasional menurut definisi ilmu ekonomi. Kaum Neoklasik boleh saja membatasi perilaku manusia sebagai gejala ekonomi, terutama harga dan kuantitas barang dan jasa. Dalam ekonomi makro perilaku ekonomi direpresentasikan oleh volume uang, pertumbuhan ekonomi, investasi, inflasi dan deflasi. Perilaku jenis kedua inilah yang selama ini diukur dengan statistik. Akan tetapi, tidak jarang perilaku manusia dipengaruhi oleh moral, terutama agama, seperti bersedekah, berpuasa dan tindakan karitatif lain. Apakah ketika seseorang bersedekah dianggap tidak rasional karena pelakunya tidak dapat mengoptimalkan kepuasan? ${ }^{5}$

Kuantifikasi perilaku ekonomi pada satu sisi mungkin memudahkan tujuan prediksi dan eksplanasi, tetapi pada sisi lain terjebak pada simplifikasi ilmu ekonomi terhadap

${ }^{1}$ Tujuan prediksi dalam ilmu ekonomi berkaitan pengetahuan inferensial yang dikatakan sebelum terjadinya sebuah peristiwa ekonomi yang benar-benar akan terjadi atau diharapkan terjadi yang dibuat berdasarkan keteraturan yang ditemukan dalam pengalaman masa lalu. Tim Penulis Rosda, Kamus Filsafat, Bandung, Remaja Rosda Karya, 2009, lema "Prediction”, 236.

2 Fungsi eksplanasi dalam ilmu ekonomi memiliki pengertian sebagai penjelasan tentang fenomena, aktivitas, fungsi dan tindakan ekonomi yang saling terkait. Penjelasan di sini bersifat ilmiah (scienific explanation) maupun mekanis (mechanistic explanation). Penjelasan ilmiah dalam ekonomi dilakukan dengan cara mendeskripsikan apa struktur dan proses ekonomi atau menunjukkan bagaimana seseorang melakukan suatu tindakan ekonomi.. Ibid, "explanation", 109-110.

${ }^{3}$ Sugiyono, Metode Penelitian Kuantitatif, Bandung: Alfabeta, 2017, 4.

${ }^{4}$ M. Firmansyah dkk., "Perdebatan Rasionalitas dalam Menjelaskan Terbentuknya ada Seleksi Pegawai Negeri”, Jurnal Ekonomi dan Pembangunan Indonesia, Vol. 13 No. 1, Juli 2012, 70.

${ }^{5}$ Dawam Rahardjo, Kritik Nalar Islamisme dan Kebangkitan Islam (Jakarta: Freedom Institute, 2012), 121. 
perlaku ekonomi disebut oleh dawam Rahardjo sebagai naif dan mengingkari realitas. Semestinya perilaku ekonomi dikebalikan pada rumusan awal ketika ekonomi pertama kali hadir dalam wujud yang lebih relevan dengan sekarang. Dalam hal ini ekonomi Islam semestinya mengajukan antitesis dengan memaparkan konsep rasionalitasnya sendiri yang dibangun di atas kerangka hubungan segitiga (triangle relationship) individu-tuhanmasyarakat. Berdasarkan hubungan segitiga tersebut, manusia dalam ekonomi Islam tidak terisolir dalam rasionalitas sempit sebagaimana dalam ekonomi konvensional. Perilaku manusia dalam ekonomi Islam tidak hanya didasarkan pada tendensi pemenuhan kebutuhan dan maksimisasi profit, tetapi mempertimbangkan kemaslahatan luas menurut garis syari'at Islam. Konsep inilah yang penulis sebut sebagai rasionalitas Islami dan menjadi dasar bagi pengembangan studi ekonomi Islam.

Topik tentang rasionalitas Islam menjadi salah satu pusat perhatian dalam penelitian ekonomi Islam. Hal tersebut tidak terlepas dari kedudukannya yang sangat penting ketika seseorang ingin memahami basis teori ekonomi Islam dan perbedaannya dengan sistem ekonomi lain. Oleh karena itu sejumlah penelitian mengulas topik ini dalam perspektif yang berbeda-beda. Dewi Maharani dan Taufiq Hidayat misalnya, dalam tulisannya yang berjudul Rasionalitas Muslim, Perilaku Konsumsi dalam Prespektif Ekonomi Islam membahas konsep rasionalitas sebagai perlaku konsumen muslim. Penelitian literatur yang mereka lakukan menyimpulkan bahwa rasionalitas perilaku muslim dalam aktifitas konsumsi harus dilandasi pada tujuan maslahah yang dikategorikan ke dalam dharuriyah, hajizah dan tabsiniyah. $^{6}$

Sedangkan Ali Amin Isfandiar mencoba menelusuri aspek mendasar dalam konsep rasionalitas melalui pendekatan kebahasaan. Tulisannya yang berjudul Melacak Teori Rasionalitas Ekonomi Berbasis Islamic Ethics berhasil membongkar akar makna kata rasinalitas kemudian menghubungkannya dengan teori-teori dalam ekonomi Islam. ${ }^{7}$ Dengan pendekatan yang berbeda Muhammad Ngasifudin melakukan studi komparasi antara konsep rassionalitas Islam dengan Kapitalisme. Dalam artikel yang berjudul Rasionalitas dalam Ekonomi Islam, Ngasifuddin juga memperkaya pembahasannya dengan menghadirkan postulat-postulat rasionalitas, serta implikasinya terhadap beberapa sub topik, seperti konsep harta, kepemilikan, dan kesejahteraan. ${ }^{8}$

6 Dewi Maharani dan Taufiq Hidayat, "Rasionalitas Muslim, Perilaku Konsumsi dalam Prespektif Ekonomi Islam”, Jurnal Ilmiah Ekonomi Islam, Vol. 6 No. 3, 2020.

7 Ali Amin Isfandiar, "Melacak Teori Rasionalitas Ekonomi berbasis Islamic Ethics", Muqtashid, Volume 6 Nomor 2, Desember 2015.

${ }^{8}$ Muhammad Ngasifudin, “Rasionalitas dalam Ekonomi Islam”, Al-Intaj, Vo.4 No. 2, 2018. 
Konsep Rasionalitas Islami dan Implikasinya ...

Berbagai rumusan postulat rasionalitas Islam berguna untuk menganalisis perilaku ekonomi Islam, seperti perilaku konsumsi. Menurut Dita Afrina dan Siti Achiria dalam artikel berjudul "Rasionalitas Muslim terhadap Perilaku Israf dalam Konsumsi Perspektif Ekonomi Islam”, konsumsi Islami tidak boleh berlebih-lebihan (israf) dan sia-sia (tabəir). Perilaku konsumsi Islam sebaliknya harus memperhatikan variabel halal dan haram serta diimbangi dengan pemenuhan kewajiban zakat dan pengeluaran karitatif lain, seperti shadaqah dan infaq. ${ }^{9}$

Pada tataran praksis, rasionalitas dapat diukur dari kepatuhan syari'ah (shariah compliace) pada institusi binsis seperti perbankan syari'ah. Dimas Bagus Wiranatakusuma dkk melalui melakukan pengukuran tersebut melalui tulisannya berjudul "Kajian Konsep Rasionalitas dan Maslahah dalam pengembangan Perbankan Syari'ah: Studi Perbandingan antara Indonesia dan Malaysia". Melalui analisis fungsi permintaan Hicsian dan Marshalian, Dimas dkk menemukan bahwa maslahah yang merupakan aktualisasi rasionalitas Islam pada perbankan syari'ah di Indonesia lebih besar dibanding di Malaysia. Maslahah dapat ditingkatkan jika usaha yang diarahkan pada perbuatan baik bisa dimaksimalkan. Bagi perbankan syari'ah perbuatan baik tersebut tercermin dalam usaha atau produk jasa yang dikembangkan. ${ }^{10}$

Meskipun memiliki kesamaan topik, rasionalitas, akan tetapi beberapa tulisan di atas tidak ada satupun yang menggunakan pendekatan studi tokoh. Paparan konsep rasionalitas Islam dalam beberapa tulisan di atas lebih menekankan pada pemetaan kesamaan dan perbedaan konsep rasionalitas dalam ekonomi Islam dan ekonomi konvensional. Sedangkan dalam tulisan ini, posisi pemikiran tokoh menjadi sangat penting karena tujuannya adalah merekonstruksi gagasan dari para intelektual klasik Islam tentang rasionalitas. Gagasan tersebut pada awalnya disajikan dalam perspektif filsafat, tasawuf bahkan fiqh.

Meskipun demikian, otentisitas pemikiran para tokoh seperti al-Gazali, Ibn Khaldun, Ibn Miskawah, al-Mawardi dan Ibn Miskawaih tetap memiliki relevansi yang kuat dengan ekonomi Islam. Pemikiran para tokoh tersebut tentang manusia dan perilakunya sangat relevan untuk direkonstruksi menjadi konsep rasionalitas Islami. Melalui kritik internal_mengkaji topik rasionalitas dari karya para tokoh yang telah disebutkan_ dan kritik eksternal_melakukan perbandingan antar sumber_rekonstruksi konsep rasionalitas

${ }_{9}^{9}$ Dita Afrina dan Siti Achiria, "Rasionalitas Muslim terhadap Perilaku Israf dalam Konsumsi Perspektif Ekonomi Islam”, Ekbis, Jurnal Ekonomi dan Bisnis, Vol. 2 No. 1, 23-38.

${ }^{10}$ Dimas Bagus Wiranatakusuma dkk "Kajian Konsep Rasionalitas dan Maslahah dalam pengembangan Perbankan Syari'ah: Studi Perbandingan antara Indonesia dan Malaysia”, Jurnal Ekonomi dan Studi Pembangunan, vol. 17 Nomor 1 April 2016, 77-88. 
ekonomi Islam dilakukan. Sedangkan untuk memperluas cakupan pembahasan, penting menghadirkan kritik rasionalitas ala neoklasik yang dikemukakan para ekonom anti mainstream seperti seperti Boulding dan sosiologi ekonomi.

Menurut Boulding, dalam mengkaji ekonomi tidak cukup hanya memusatkan perhatian pada perilaku individu sebagai homo economicus. Secara spesfisik ia merekomendasikan agar melibatkan perspektif politik, sebab: pertama, ilmu ekonomi juga membahas faktor kekuasaan dan kekuatan dalam persoalan ekonomi, sehingga masalah ekonomi perlu dianalisis dari pendekatan ilmu politik (politik-ekonomi). Alokasi sumber daya yang menjadi problem utama dalam ekonomi dipandang sebagai masalah kekuasaan atau politik. Kedua, bahwa gejala politik semestinya juga dipandang sebagai masalah ekonomi. Gejala kekuasaan (politik) dianggap sebagai suatu sumber daya sehingga harus dikelola menurut prinsip-prinsip ekonomi yang efisien. ${ }^{11}$

Sedangkan studi sosiologi ekonomi menegaskan bahwa sebenarnya tugas ekonomi bukan melakukan prediksi, tetapi sekedar mendeskripsikan dan menjelaskan secara mendalam terhadap suatu fenomena secara kualitatif, mengungkap apa yang ada di balik realitas. ${ }^{12}$ Justru karena keengganan itu, dalam menjelaskan perilaku manusia sosiologi memiliki lebih banyak pilihan metode seperti hermeneutik, etnografi, fenomenologi, sejarah dan sebagainya. Jika dalam ekonomi data yang digunakan harus data resmi (data skunder), maka data yang digunakan dalam sosiologi ditelusuri langsung dari lapangan, sehingga lebih kaya dan lebih mampu menelisik dimensi dalam pada diri manusia. ${ }^{13}$ Keluwesan pandangan ekonomi politik dan sosiologi tersebut digunakan untuk kepentingan rekonstruksi konsep rasionalitas islami.

\section{B. Pembahasan}

\section{Diskursus Rasionalitas Ekonomi}

Sekalipun dianggap sebagai isu paling mendasar dalam ilmu ekonomi, para pakar tidak pernah benar-benar sepakat tentang definisi rasionalitas. Aliran Neoklasik menekankan asumsi rasionalitas ekonomi pada dua aspek, yaitu kepentingan pribadi (self interest) dan maksimisasi fungsi guna (maximization of utility). Secara teknis manusia selalu melakukan kalkulasi-kalkulasi manfaat dan biaya dalam setiap keputusan dan tindakannya. Keputusan dan tindakan dianggap rasional apabila biaya lebih kecil daripada fungsi guna yang diperoleh. Sementara faktor-faktor eksternal seperti nilai dan aturan yang berlaku di

11 Ibid., 123.

12 Damsar dan Indrayani, Pengantar Sosiologi Ekonomi, ed. 2, cet. 3. (Jakarta: Kencana Prenadamedia Group, 2013), 47.

${ }^{13} \mathrm{Ibid}, 48$. 
Konsep Rasionalitas Islami dan Implikasinya ...

masyarakat, sekalipun seringkali mempengaruhi keputusan dan tindakan, tidak diperhitungkan sama sekali. ${ }^{14}$

Rasionalitas ala Neoklasik terbentuk dari perkenalan langsung (direct aquitance) seseorang dengan obyek perilaku yang teriri atas tiga komponen, yaitu: pengalaman (experience), pemahaman (understanding) dan persepsi (perception). Perilaku rasional seseorang pada umumnya didasarkan pada pengalaman yang dia peroleh, dipelajari dan dijadikan dasar atas suatu tindakan. Pengalaman membentuk memori yang menjadi pedoman dalam berperilaku. Sedangkan memahami adalah dasar bagi rasionalitas, dalam arti seseorang tidak mungkin melakukan suatu tindakan yang tidak dia pahami. Sedangkan persepsi memicu suatu perilaku, seperti persepsi atas manfaat suatu tindakan, serta konsekuensi atas tindakannya. Jika seseorang mempersepsikan tindakannya bermanfaat dan berakibat baik, maka dia akan melakukannya, dan sebaliknya. ${ }^{15}$

Sementara itu, kebiasaan (habits) dan rutinitas (routins) dianggap sebagai faktor pembentuk rasionalitas oleh kalangan Old Institutional Economics (OIE). Keputusan yang dibuat oleh individu atau kelompok berdasarkan pengetahuan dan pengalaman menjadi parameter rasionalitas. Bagi Veblen_pemuka OIE_ kebiasaan dan rutinitas berperan sebagai pembentuk raionalitas. Dukungan terhadap pendapat OIE datang dari New Institutional Economics (NIE) yang menyatakan bahwa rutinitas yang dilakukan seseorang dapat membentuk kebiasaan baru sehingga pada saaat dibutuhkan mengambil keputusan tanpa berpikir, itulah yang dimaksud dengan rasionalitas. ${ }^{16}$

Konsep rasionalitas mengalami perluasan definisi di tangan sosiologi dengan memasukkan pertimbangan-pertimbangan norma, nilai, struktur sosial dan faktor-faktor eksternal di luar diri individu. Sementara kalangan psikolog justru memperkuat faktor internal berupa kepribadian individu. Dengan begitu, tindakan individu tetap dikatakan rasional sekalipun berbeda dengan anggota kelompoknya karena hal itu mencerminkan kepribadian si pelakunya. ${ }^{17}$

Sekalipun memiliki perspektif yang berbeda-beda, kriteria rasionalitas di kalangan ekonomi, sosiolog dan psikolog memiliki benang merah, dimana faktor penentu rasionalitas adalah hal-hal yang bersifat nisbi. Baik pengalaman, pemahaman dan persepsi ala Neoklasik, kebiasaan dan rutinitas menurut OIE dan NIE tidak memiliki parameter yang jelas. Sebab parameter yang sudah disebutkan di atas akan selalu mengalami

\footnotetext{
${ }^{14}$ M. Firmansyah, dkk, "Perdebatan", 71.

${ }^{15}$ Ibid., 73.

${ }^{16} \mathrm{Ibid}, 75-77$.

${ }^{17}$ Ibid, 79-80.
} 
perubahan sehingga kriteria rasionalitas juga akan berubah. Sekalipun sosiolog memasukkan unsur norma dan nilai, tetapi lagi-lagi keduanya terbentuk oleh kesepakatan kelompok masyarakat. Apalagi penekanan yang berlebihan kalangan psikolog terhadap unsur kepribadian. Konsekuensinya adalah, tidak ada kriteria rasionalitas yang jelas pada teori-teori di atas. Padahal, kemampuan eksplanasi dan prediksi yang merupakan kekuatan ilmu ekonomi membutuhkan paramater yang jelas dan tidak relatif.

Kejelasan parameter rasionalitas ditemukan dalam ekonomi Islam, dimana nilai-nilai agama secara substantif selalu relevan dengan perilaku manusia dalam kondisi bagaimanapun, serta tidak mengalami pergeseran. Rumusan prinsip Islam yang dilakukan Naqvi berupa tauhid, keadilan, kebebasan berkehendak, pertanggungjawaban, serta pertimbangan halal haram adalah kriteria rasionalitas yang sesungguhnya. ${ }^{18}$ Prinsipprinsip trersebut dirumuskan bersumber dari al-Qur'an, as-Sunnah maupun perbendaharaan pemikiran Islam klasik, seperti al-Gazali, alo-Mawardi, Ibn Khaldun dan sebagainya.

\section{Rasionalitas Ekonomi Islam dalam Islam}

a. Pandangan Filosofis Islam Tentang Manusia sebagai Dasar Rasionalitas

Konsepsi tentang manusia merupakan dasar bagi perumusan suatu teori ekonomi. Dari pandangan filosofis mengenai manusia sebagai homo economicus Neoklasik berhasil merumuskan perilaku manusia sebagai peristiwa yang teramati dan terukur untuk selanjutnya disusun teori ekonomi secara akurat. Demikian pula dengan ragam teori ekonomi yang lain.

Dalam pandangan Islam, pandangan filosofis tentang manusia sangat kompleks. Pendekatan kebahasaan yang ditempuh oleh kalangan mufassir menemukan termaterma al-basyar, al-insa $>n$ dan bani $>$ a $>$ dam. Berbagai terma tersebut dapat dilihat sebagai konstuk sosial dan relijius manusia, dimana kedudukannya tidak saja sebagai individu yang bersifat biologis, melaikan kompleksitas substansi yang diberi akal pikiran dan kemampuan berbicara, sebagaimana tercermin dari konsep al-insa $>n$. Dengan kapasitasnya tersebut manusia dapat menjadikan dirinya sebagai sosok ideal (insa $>n$ ka $>$ mil) yang berhak menyandang status sebagai khali $>$ fah. Kedudukan mulia tersebut dipandang sebagai implikasi logis dari usaha manusia yang mampu memaksimalkan potensi basyariyah-nya, berupa daya pengindera dan dihubungkan dengan potensi insaniyah-nya berupa akal. Puncak dari proses tersebut menjadikan 1985), 9 .

\footnotetext{
${ }^{18}$ Syed Nawab Haidar Naqvi, etika dan Ilmu Ekonomi, Suatu Sintesis Islami, (Bandung: Mizan,
} 
Konsep Rasionalitas Islami dan Implikasinya ...

manusia sebagai makhluk sosial yang membentuk struktur masyarakat relijius. Tugas masyarakat relijius ini (bani $>a>$ dam) tidak lain adalah menjalankan ketentuanketentuan Allah, sebagaimana tugas kenabian yang melekat pada nabi Adam, melalui segenap potensi yang dimilikinya.

Konsep filosofis manusia di atas mendapat penegasan dari berbagai pandangan aliran filosofis, telogis dan reljius, dimana ketiganya menguraikan berbagai konsep yang saling bersinggungan. Struktur manusia disebutkan terdiri atas fisik (jism), nyawa $(r u>h)$, hati (qalb) dan akal ('aqD). Struktur yang komlpleks tersebut pada dasarnya menjelaskan potensi-potensi yang dimiliki manusia untuk menentukan pilihan-pilihan baik dan buruk, benar dan salah. Manusia memiliki kendali atas pilihan dan keputusan yang dibuat sendiri, tergantung pada potensi mana yang dia maksimalkan. Manusia dapat menjadi baik manakala memaksimalkan potensi qalb untuk mengambil keputusan yang sesuai dengan ajaran Allah. Sebaliknya manusia juga dapat mejadi buruk dengan memaksimalkan potensi nafs al-h\}ayawa $>$ niyah.

Konsep filosofis manusia tersebut memiliki implikasi teoretis yang serius terdahap posisi manusia. Dengan melihat kompleksitas struktur dan potensi yang dimilikinya, manusia bukanlah sekedar makhluk rasional yang sekedar mengejar kepentingan (keuntungan) pribadi sebagaiman dalam pandangan ekonomi konvensional. Manusia juga bukan sosok yang bertindak seperti robot sehingga melakukan pengulanganpengulangan tindakan tanpa adanya pertimbangan tertentu yang mendasari keputusannya. Dengan kedudukannya manusia semestinya tidak didominasi oleh faktor-faktor eksternal, seperti teknologi dan peristiwa-peristiwa ekonomi sebagaimana dalam fenomena inhumanisme. ${ }^{19}$

b. Definisi dan Batas-batas Rasionalitas Islami

Konsep rasionalitas ekonomi konvensional yang dikembangkan atas dasar ideologi Neoklasik menempatkan individu sebagai homo economicus yang 'beriman' pada teori evolusi Darwin survival of the fittest. Faktor utama yang menggerakkan aktivitas ekonomi setiap individu tidak lain adalah motif memperoleh keuntungan dan kepuasan yang diukur dengan parameter materi secara kuantitatif. ${ }^{20}$ Dalam hal ini Smith menekankan bahwa individu yang mencari keuntungan melalui aktivitas bisnis tidaklah salah, hanya saja melalui rasa simpatinya, individu menurut Smith harus bersimpati

\footnotetext{
${ }^{19}$ Stuart Sim, Lyotard dan Nirmanusia, terj. Ab. Sigit Djatmiko (Yogyakarta: Penerbit Jendela, 2003), 14-15.

${ }^{20}$ Hafidz MS., Sya'roni dan Marlina, "Etika Bisnis Al-Ghazali dan Adam Smith dalam Perspektif Ilmu Bisnis dan Ekonomi“", Jurnal Penelitian, Vol. 9 No. 1 Mei 2021, 21
} 
kepada orang lain. Namun dalam The Wealth-nya, Smith menyatakan bahwa motif seseorang untuk melakukan aktivitas ekonominya adalah untuk memenuhi selfinterest.

Pengaruh ideologi ekonomi yang bersandar pada self-interest inilah yang dalam perkembangannya kelak memunculkan mitos bisnis amoral. Richard T. De George, pakar etika bisnis yang mengintrodusir mitos bisnis amoral, menyatakan bahwa tidak ada keterkaitan apapun antara bisnis dan moralitas, sehingga merupakan kekeliruan jika kegiatan bisnis dinilai dengan menggunakan tolok ukur moralitas. Bahkan pada gilirannya, mitos bisnis amoral ini berkembang menjadi sebuah teori yang berdiri sendiri, yaitu theory of amorality. ${ }^{21}$

Pandangan Islam tentang rasionalitas juga berpusat pada konsepsi manusia sebagai makhluk rasional. Dalam pengertian yang disepakati mayoritas ulama, ukuran rasionalitas adalah keberadaan dan fungsi $\mathrm{akal}^{22}$ yang melekat pada diri manusia sebagai unsur yang mampu menyerap pengetahuan, mencerna dan mengambil keputusan. Hanya saja, rasionalitas dalam Islam tidak terisolasi sendirian, melainkan dibarengi dengan variabel etis. Al-Mawardi menyatakan bahwa orang yang berakal adalah mereka yang mampu menjalankan perintah dan menjauhi larangan Allah. Karena dengan akal manusia diasumsikan mampu menyelesaikan persoalan-persoalan yang dihadapinya secara tuntas, tidak terkecuali persoalan-persoalan ekonomi. Namun begitu, rasionalitas dalam pandangan Al-Mawardi tidak bersifat independen. Kemampuannya menyelesaikan masalah membutuhkan intervensi dari petunjuk Allah. Oleh karenanya, orang yang memiliki integritas dalam perilakunya adalah yang memiliki kualifikasi rasional-relijius. $^{23}$

Al-Ghazali memperluas definisi rasionalitas (al-aql = akal) mencakup empat aspek; Pertama, suatu kategori yang menjadi distingsi manusia dengan makhluq lain, khususnya binatang. Dengan akal manusia mampu menerima pengetahuan serta mengolah bermacam - macam konsep yang detail. Mengutip pernyataan al-H $\}$ ars $\mid$ ibn Assa $>$ d al-Muh $\}$ a $>$ sibi $>$, al-Gaza $>$ li $<$ menyebut akal sebagai unsur bawaan manusia yang dapat mencerna pengetahuan seperti cahaya yang terpercik di dalam hati sehingga mampu mengetahui berbagai obyek. Kedua, rasionalitas terkadang digunakan untuk pengertian yang merujuk pada batas pengetahuan yang seorang anak dianggap mumayyiy

\footnotetext{
${ }^{21}$ Ibid., 19-22.
}

${ }^{22}$ Al-Ima>m al-'Alla>mah Abu> al-Fad \}1 Jama>1 al-Di>n Muh\}ammad ibn Mukrim ibn Manz\}u $>$ r al-Ifri>qi> Al-Mis\}ri, Lisa>n al-'Ara>b, (9 jilid), Da>r al-Qa>dir, Cet. V, Beirut: Ba>b: 'Ain-Qaf-La>m, 2005.

${ }^{23}$ Al-Mawardi, Ada>b ad-Dunya $>$ wa $a d-D i>n$ (Beirut: Da>r Kutub al-'Ilmiyah, 2013), 5 
Konsep Rasionalitas Islami dan Implikasinya ...

(cakap hukum), seperti kemampuan membedakan antara mustah\}i $>l$ dan mumkin, mengetahu bahwa dua lebih banyak daripada satu, atau tidak mungkin seseorang berada di dua tempat pada saat yang bersamaan. Pengertian ini menurut al-Ghazali sejalan dengan definisi yang berlaku di kalangan mutakallimun bahwa rasionalitas adalah sebagian ilmu $d$;aru>ri> (bawaan) yang memiliki kebenaran instrinsik. Ketiga, rasionalitas juga dapat didefinisikan sebagai pengetahuan yang dihasilkan dari proses eksperimen terhadap fenomena tertentu. Berdasarkan definisi ini orang yang mampu menyerap pengetahuan dari proses eksperimen dapat disebut berakal, sebaliknya orang yang tidak memiliki kemampuan tersebut dikateogrikan sebagai orang yang bodoh. Keempat, rasionalitas juga berarti batas kemampuan akal untuk mengetahui dampak atau akibat yang ditimbulkan oleh sesuatu perbuatan atau kejadian. Kemampuan ini menyebabkan seseorang dapat disebut berakal. ${ }^{24}$

Sebenarnya Adam Smith juga memasukkan unsur etis dalam rasionalitas. Dalam The Wealth of Nations dia katakan bahwa orang yang terlibat dalam aktifitas ekonomi tidak selayaknya berbuat egois, apalagi keserakahan. Kegiatan ekonomi menuntut sikap etis atau keutamaan. Sikap etis yang penting dalam ekonomi adalah hubungan timbal balik (reciprocity), kerjasama (cooperation) dan terutama adalah keadilan. ${ }^{25}$ Hanya saja sebagaimana terlihat, rumusan Smith masih dalam kerangka pemenuhan kebutuhan dan pencapaian keuntungan. Ketiadaan pertimbangan agama menjadikan konsep rasionalitasnya bersifat sekuler. Dari perbandingan tersebut, tampak jelas bahwa konsep rasionaltas dalam ekonomi Islam berbeda dengan ekonomi konvensional. Rasionalitas dalam ekonomi Islam selalu melibatkan variabel lain, berupa etika yang bersumber pada kesadaran spiritualitas. Karena itu ekonomi Islam juga menegasikan konsep homo economicus.

Rasionalitas manusia dalam rumusan ekonomi Islam juga berkaitan dengan struktur pengetahuan, dimana dikenal adanya dua level pengetahuan; pengetahuan Allah dan pengetahuan manusia. Pengetahuan Allah yang bersifat absolut tidak mengenal batas ruang dan waktu. Sedangkan pengetahuan manusia bersifat relatif. Pembagian level pengetahuan ini terscermin dalam perdebatan kelompok etika teologis, antara Mu'tazilah, Ahlussunnah, Murji'ah dan sekte-sekte lainnya. Sekalipun terdapat perbedaan dalam batas-batas independensi pengetahuan manusia, tetapi secara garis besar mereka sepakat dengan pembagian level pengetahuan tersebut. Hal

\footnotetext{
${ }^{24}$ Al-Gaza>li>, Ihłya> 'Ulu>m ad-Din (Semarang: Nur Asia, tt), vol. I, 84-85.

${ }^{25}$ Hafidz MS., Sya'roni dan Marlina, "Etika”, 19.
} 
ini membawa konsekuensi logis, bahwa rasionalitas manusia tidak mungkin melampaui rasionalitas Tuhan. Keputusan-keputusan rasional dalam bidang ekonomi dengan demikian tidak boleh melanggar atura-atura agama yang didasarkan pada rasionalitas Tuhan. Dengan ungkapan lain, rasioalitas manusia menjadi dasar bagi pembebanan (takli>f) yang diberikan Allah sebagaimana dikemukakan oleh al-Mawardi.

c. Rasionalitas Tindakan Manusia sebagai Aktor dalam Ekonomi

Dalam memahami konsep aktor, studi ekonomi meletakkan dasar analisisnya pada pandangan utiliarianisme yang sangat memperhatikan individu. Doktrin utilitarianisme memandang individu sebagai makhluk rasional yang memiliki watak dasar membuat perhitungan-perhitungan dan pilihan untuk memperbesar keuntungan atau kesenangan pribadi, serta selalu berusaha mengurangi penderitaan dan menekan biaya. Dalam sistem ekonomi Neoklasik yang dibangun di atas faham utilitarianisme, watak dasar ini diterjemahkan ke dalam prinsip laissez fire, laissezpasser (biarkan hal-hal sendiri, biarkan hal-hal baik masuk). Prinsip ini mengandung makna untuk memberi kebebasan individu secara mutlak dalam mengatur dirinya sendiri dengan anggapan bahwa dialah yang paling mengetahui keinginannya. Kontrol negara sebisa mungkin diminimalisir dan kalaupun ada diarahkan untuk menjaga agar kebebasan individu tetap terjamin. ${ }^{26}$

Ilmu ekonomi menempatkan individu dengan segala tindakannya sebagai pihak yang terisolasi dari pihak dan tindakan orang lain. Secara otonom, individu yang merupakan aktor memiliki kemampuan untuk membuat keputusan dan melaksanakan keputusan tersebut dalam alokasi sumber daya yang terbatas dengan mempertimbangkan kemampuan usaha dan keinginannya. ${ }^{27}$ Aktifitas ekonomi dipandang sebagai gejala bagaimana individu-individu di dalam masyarakat memenuhi kebutuhan mereka terhadap barang dan jasa melalui cara-cara produksi, distribusi, pertukaran dan konsumsi barang serta jasa yang langka.

Berkebalikan dengan ekonomi, studi sosiologi mengarahkan perhatiannya pada aktor dalam konstruk sosial. Dalam hal ini, terdapat dua frasa kunci untuk memahami konsep aktor dalam sosiologi, yaitu "aktor dalam interaksi" dan "aktor dalam masyarakat". Aktor dalam interaksi adalah setiap individu yang terlibat dalam suatu interaksi dengan individu atau kelompok lain. Pada tataran ini, individu dianggap sebagai aktor yang kreatif menciptakan, mempertahankan dan merubah dunianya pada saat interaksi berlangsung. Sedangkan aktor dalam masyarakat adalah individu yang

\footnotetext{
${ }^{26}$ Damsar dan Indrayani, Pengantar Sosiologi Ekonomi, , 36

${ }^{27}$ Ibid., $\quad 35$
} 
Konsep Rasionalitas Islami dan Implikasinya ...

identitas dirinya tidak terlihat, tetapi tersembunyi dalam suatu kesatuan yang disebut masyarakat. Dengan demikian masyarakat merupakan satu kesatuan utuh atau suatu entitas sendiri yang dikenal sebagai suatu fenomena sui generis, berbeda dari individuindividu yang membentuknya.

Tindakan aktor yang menjadi perhatian sosiologi adalah tindakan aktor yang memperhatikan tingkah laku individu lain dan oleh karenanya diarahkan pada tujuan tertentu (tidak terisolir, tidak netral). ${ }^{28}$ Aktor tidak direpresentasikan oleh individu itu sendiri, tetapi individu yang dihubungkan dengan individu lainnya. Dalam ungkapan Smith, kebahagiaan dan kesempurnaan individu harus mempertimbangkan bahwa dirinya adalah anggota dari sebuah keluarga, negara dan masyarakat luas. ${ }^{29}$ Tindakan aktor dapat disebut sebagai tindakan sosial jika memperhatikan tingkah laku aktor lain.

Konsepsi ekonomi Islam tentang aktor menempakan manusia tidak saja sebagai individu yang berada dalam dimensi sosial, tetapi juga sebagai makhluk yang etisrelijius. Hal ini menunjukkan dalam ekonomi Islam, nilai-nilai agama memegang peranan penting sebagai pedoman bagi manusia dalam berperilaku. Aktualisasi dari nilai-nilai agama tercermin dalam perilaku yang ideal (akbla $>q$ kari $>$ mab). Menurut Magnis Suseno, setidaknya ada tiga fungsi etika (agama) dalam kehidupan manusia, yaitu: sebagai panduan dalam memilih apa yang diperbolehkan dan apa yang dilarang, sebagai daya pertahanan menghadapi berbagai ideologi kontemporer, sebagai benteng menghadapi perilaku menyimpang. ${ }^{30}$

Status manusia sebagai makhluk etis-relijius, tidak berarti mengingkari kenyataan bahwa manusia juga memiliki potensi lain yang dapat membuat perilakunya tidak selalu ideal. Dalam pandangan Ibn Miskawaih, dalam diri manusia terdapat tiga potensi, yaitu: potensi kebinatangan (an-nafs al-bahi>miya $>t$ ), potensi keliaran (an-nafs as-sabu'iya $>t$ ) dan potensi rasional (an-nafs an-na>t\}iqab). Dua potensi yang pertama bersumber dari unsur materi, sedangkan potensi yang terakhir berasal dari pancaran ruh Allah dan bersifat kekal. $^{31}$ Dengan kata lain, Ibn Miskawaih membagi unsur manusia menjadi dua, yaitu

${ }^{28}$ Ibid., 41-42.

${ }^{29}$ Ryan Patrik Hanley, Adam Smith and The Character of Virtue (Cambridge: Cambridge University Press, 2009), 81.

30 Franz Magnis Suseno, Etika Dasar: Masalah-masalah Pokok Filsafat Moral (Yogyakarta: Kanisius, 1987), 15.

${ }^{31}$ Ibn Miskawaih, Tahz $\mid i>b$ al-Akhla $>q$ wa Tat\}hi>r al-'Araq (Beirut: Mansyu>rah Da>r alMaktabah al-Haya>h. 1398 H), 62. 
unsur materi dan unsur jiwa. Keduanya bersifat saling mempengaruhi antara yang satu dengan lainnya. ${ }^{32}$

Keberadaan tiga potensi tersebut membentuk perilaku manusia untuk menjadi baik atau jahat, tergantung potensi mana yang dapat dioptimalkan. Oleh karena itu menurut al-Ghazali terkait dengan kemampuannya mengoptimalkan potensi yang dimiliki, manusia terbagi menjadi tiga macam; Pertama, orang yang disibukkan dengan urusan kehidupan dunia sehingga melupakan akhirat. Orang jenis pertama ini termasuk kelompok yang akan celaka ( $h a>l i k i>n)$. Kedua, orang yang disibukkan dengan urusan akhirat sehingga mengabaikan urusan kehidupan dunianya. Mereka inilah yang dimasukkan ke dalam kelompok orang yang akan selamat $\left(f_{a}>i \not i p n\right)$. Ketiga, orang yang disibukkan dengan mencari kehidupan yang layak di dunia dengan tujuan menjadi bekal di akhirat. Orang yang seperti ini termasuk ke dalam kelompok moderat (muqtas $\}$ idi $>n$ ). ${ }^{33}$

Paparan al-Ghazali tentang tiga-tipe manusia di atas berkaitan langsung dengan kemampuan manusia menggunakan potensinya dalam bidang ekonomi. Ia menekankan agar orang memilih pada kelompok yang ketiga (moderat), yaitu yang dengan potensinya mampu menjaga keseimbangan aspek duniawi dan ukhrawi. Aspek duniawi harus dikuasai manusia dan selanjutnya dijadikan sebagai sarana meraih kebahagiaan di akhirat. Menurut Ibn Miskawaih, Sikap moderat sebagaimana dianjurkan al-Ghazali dapat ditempuh melalui iffah, yaitu menjaga diri dari perbuatan dosa dan maksiat, mempertimbangkan untung dan rugi dari setiap tindakan yang didorong oleh potensi kebinatangan, serta menanamkan kebijaksanaan. ${ }^{34}$ Sementara menurut al-Ghazali, agar seseorang dapat termasuk ke dalam kelompok yang moderat harus menempuh metode yang telah ditetapkan oleh syari'ah. Yang dimaksud dengan metode syari'at di sini mencakup lima hal, yaitu: (1) mengetahui keutamaan dan dorongan bekerja, (2) mengetahui syarat syah dan ketentuan mu'amalah seperti jualbeli, (3) mengetahui prinsip-prinsip keadilan dalam bermu'amalah, (4) mengetahui etika bermu'amalah serta (5) etika pedagang (pelaku ekonomi) dalam urusan dirinya dan agamanya. ${ }^{35}$ 2000), 7-8

${ }^{32}$ Abuddin Nata, Pemikiran Para Tokoh Pendidikan Islam (Jakarta : PT. Raja Grafindo Persada,

${ }^{33} \mathrm{Al}-\mathrm{Gaza}>\mathrm{li}>$, Ih y $\mathrm{y}$ >, vol. II, 62

${ }^{34}$ Ibn Miskawaih, Tahz| $i>b, 25$.

35 Al-Gaza>li $>$, Ih/ya $>$, vol. II, 63. 
Konsep Rasionalitas Islami dan Implikasinya ...

Berdasarkan penjelasan tersebut dapat dipahami bahwa al-Ghazali maupun Ibn Miskawaih tidak memandang manusia semata-mata sebagai makhluk ekonomi (bomo economicus) yang dalam melakukan tindakan ekonomi didasari motif-motif materiil saja. Keduanya merepresentasikan pandangan Islam tentang manusia sebagai makhluk etisreljius. Rasionalitas dalam konsep ekonomi Islam didasarkan pada kemampuan manusia sebagai aktor ekonomi menyelaraskan potensi rasionalitasnya dengan tuntunan agama atau syari'at. Konsepsi ini membawa konsekuensi pada semakin kompleksnya pertimbangan aktor dalam membuat keputusan ekonomi, tetapi pada saat yang sama juga memiliki pandauan yang jelas dan tegas bagi batasan keputusan yang dibuatnya sendiri. Aktor dalam ekonomi Islam tidak cukup menjadikan untuk-rugi dan pandangan masyarakat umum sebagai pertimbangan logis. Dimensi spiritual menjadi bagian yang tidak terpisahkan sebagai faktor penentu apakah suatu keputusan dan tindakan akan diambil ataukah tidak.

Konsekuensi dari cara pandang ilmu ekonomi terhadap aktor sebagai makhluk rasional, menempatkan aktor sebagai pihak yang memiliki sejumlah pilihan dan preferensi dimana semua pilihan atau prefrerensi tersebut telah tersedia dan bersifat stabil. Tindakan aktor dalam ekonomi adalah untuk memaksimalkan pemanfaatan dan keuntungan.Semua tindakan aktor dalam rangka maksimalisasi pemanfaatan dan keuntungan tersebut hanya memiliki satu kemungkinan, yakni bahwa tindakan aktor merupakan tindakan ekonomi rasional. $^{36}$ Motif dari tindakan ekonomi adalah maksimisasi keuntungan atau manfaat sumber yang dimiliki di tengah kelangkaan (scarcity) sumberdaya itu sendiri. Dalam prspektif filsafat moral, tujuan ekonomi adalah untuk meraih kenikmatan atau kebahagiaan dengan berbagai batasan dan definisinya. Tentu saja ekonomi konvensional membatasi pada aspek-aspek lahiriyah.

Ekonomi mengasumsikan aktor sebagai pihak yang memiliki sejumlah pilihan dan preferensi dimana pilihan-pilihan dan prefrerensi tersebut telah tersedia dan bersifat stabil. Tindakan aktor dalam ekonomi adalah untuk memaksimalkan pemanfaatan dan keuntungan. Sedangan sosiologi melihat adanya beberapa kemungkinan (menurut Weber ada 3 kemungkinan) dari tindakan aktor, yaitu: rasional, tradisional dan spekulatif-irrasional. ${ }^{37}$ Jika tindakan ekonomi rasional didasarkan pada kemampuan individu dalam memanfaatkan pilihan dan preferensi yang tersedia, kedua tindakan lainnya dipengaruhi dan ditentukan oleh faktor eksternal. Faktor eksternal pada

\footnotetext{
${ }^{36}$ Damsar dan Indrayani, Pengantar, 42.

${ }^{37}$ Ibid.
} 
tindakan tradisional berupa kebiasaan (custom), sementara pada tindakan spekulatifirrasional faktor eksternal tersebut berupa pengabaian terhadap sejumlah instrument dalam mencapai suatu tujuan ekonomi melalui tindakan ekonomi yang dilakukan. ${ }^{38}$ Faktor eksternal pada tindakan ekonomi tradisional dapat digambarkan melalui kebiasaan memberi kado atau hadiah, memberikan sumbangan, oleh-oleh dan tindakan karitatif lainnya. Sedangkan faktor eksternal pada tindakan spekulatif-irrasional dapat dicontohkan melalui kasus sebagian warga yang mudah tertipu oleh penipuan investasi dengan janji memberikan imbalan tinggi.

Ekonomi Islam menempatkan tindakan manusia (aktor) tidak terlepas dari kehendak (ira $>$ dah) dan perbuatan Allah. Perdebatan aliran teologis mengenai apakah seluruh tindakan manusia telah dikehendaki dan dikendalikan oleh Allah, sehingga baik dan buruk keluar dari konteks dirinya sendiri, menunjukkan pada keharusan untuk selalu menyelaraskan tindakannya dengan tindakan Allah. Perbedaan dari cara pandang ekonomi dan sosiologi terhadap tindakan ekonomi adalah, pertama, jika dalam ekonomi tindakan rasional dianggap sebagai asumsi, maka dalam sosiologi tindakan rasional hanyalah variabel (dari sejumlah variable lainnya). Kedua, Secara praktis, ekonomi memandang tindakan ekonomi selalu berhubungan dengan selera dan kuantitas barang dan jasa, sementara dalam sosiologi setiap tindakan ekonomi harus dikonstruk secara historis dan harus diselidiki secara empiris, tidak dapat secara langsung melalui asumsi dan lingkungan eksternalnya.Oleh karena itu, sosiologi memasukkan tindakan ekonomi sebagai salah satu bentuk tindakan sosial. Ketiga, ekonomi hanya sedikit memberikan porsi perhatian pada kekuasaan, karena dalam tindakan ekonomi kedua individu (atau kelompok) dipandang sebagai pertukaran sederajat.Sementara dalam sosiologi memberikan perhatian lebih besar pada kekuasaan pada setiap tindakan ekonomi. ${ }^{39}$

Dalam ekonomi Islam, kebahagiaan dibedakan menjadi dua macam, yaitu kebahagiaan yang berhubungan dengan perbuatan kesusilaan dan kebahagiaan yang berhubungan dengan kesempurnaan akal. Kebahagiaan yang didasarkan pada perbuatan kesusilaan dapat direalisasikan jika seseorang bersedia menjalankan hidup sesuai tuntunan agama dan anjuran filosof. Sedangkan kebahagiaan yang berdasarkan kesempurnaan akal dapat diraih hanya dengan memaksimalkan penggunaan kemampuan akal fikiran untuk mengetahui segala sesuatu. ${ }^{40}$

${ }^{38}$ Ibid, 43

${ }^{39}$ Ibid., 44-45.

${ }^{40}$ Musta'in, "Etika dan Ajaran Moral Filsafat Islam; Pemikiran Para Filosof Muslim tentang Kebahagiaan”, Ulumuna, Jurnal Studi KeIslaman, vol. 17 No. 1 (Juni) 2013, 195. 
Adanya dua jenis kebahagiaan ini dapat dilihat dalam perspektif tindakan ekonomi moral dan rasional. Tindakan seseorang yang berusaha meraih kebahagiaan dengan mengikuti aturan-aturan agama dan seruan moral termasuk dalam kategori tindakan ekonomi moral. Hal ini tercermin dalam gambaran yang dikemukakan al-Ghazali bahwa:

"Sesungguhnya Tuhan telah menjadikan akhirat sebagai hari pembalasan dan menjadikan dunia sebagai tempat berusaha, bekerja dan beraktifitas. Aktifitas di dunia tidak hanya terbatas pada urusan akhirat tanpa mengurusi kehidupan dunia. Sebaliknya kehidupan dunia menjadi perantara dan penolong menuju akhirat, karena dunia adalah tempat menanam dan tahapan bagi akhirat" ${ }^{\prime 1}$

Pernyataan di atas memberikan gambaran yang jelas bahwa kepercayaan beragama menyediakan seperangkat tuntunan tentang apa yang harus dilakukan seseorang agar dapat meraih kebahagiaannya. Al-Ghazali pada dasarnya menandaskan bahwa keputusan yang terkait dengan aktifitas ekonomi, entah itu produksi, distribusi maupun konsumsi, baik secara individu maupun agregatif hendaknya tidak hanya dibatasi oleh pertimbangan-pertimbangan ekonomisaja, semisal keuntungan (profit) atau manfaat (utilitas) dari barang atau jasa.

Akan tetapi pada kesempatan lain dia juga menjelaskan bahwa pemanfaatan kekuatan akal manusia sangat penting dalam upaya mencapai tujuan tertentu:

“.....tujuan orang berakal adalah bertemu dengan Allah Ta'ala di hari pembalasan.Tidak ada jalan untuk sampai pada Allah kecuali dengan ilmu pengetahuan dan perbuatan baik ('amal) dan tidak mungkin keduanya dicapai kecuali dengan fisik yang sehat. Fisik yang sehat tidak bisa diperoleh kecali dengan mengkonsumsi makanan yang sesuai kebutuhan energi yang diperlukan. Oleh karena itu sebagian ulama salaf menyatakan bahwa makan itu sebagian dari agama...." 42

Untuk memperkuat argumennya, al-Ghazali juga mengutip potongan ayat ${ }^{43}$.

من طيبات واعملوا صالحا . Dalam komentarnya terhadap ayat tersebut al-Ghazali menyatakan bahwa orang yang mengkonsumsi makanan dengan tujuan agar dapat menuntut ilmu dan beramal serta menjadikan bekal untuk takwa tidak boleh menghabiskan waktunya hanya untuk itu, seperti hewan ternak yang merumput di padang, karena hal itu bisa menjadi perantara bagi agama. ${ }^{44}$

Pada pernyataan yang kedua ini al-Ghazali menjelaskan tentang tindakan ekonomi rasional. Kemampuan seseorang memanfaatkan ilmu pengetahun dan mengetahui

\footnotetext{
${ }^{41}$ Al-Gaza>li>, Ihya, vol. II, 62.

${ }^{42}$ Ibid.

${ }^{43}$ Q.S. Al-Mu'minun (23): 51.

${ }^{44} \mathrm{Al}-\mathrm{Gaza}>\mathrm{li}>$, Ihya, vol. II, 62.
} 
makanan yang baik atau tidak baik menunjukkan bahwa pertimbangan-pertimbangan rasional juga sangat menentukan dalam sebuah keputusan atau tindakan ekonomi. Dengan demikian, dikotomi tindakan ekonomi menjadi moral dan rasional menjadi tidak relevan lagi. Dalam Islam keduanya merupakan satu kesatuan yang tidak dapat dipisah-pisahkan. Aspek moral memberikan garis marka yang jelas tentang tujuan dan perbuatan mana yang tidak boleh dilampui, sementara rasionalitas menjadi alat untuk mengambil keputusan efektif dari semua keputusan dan tindakan ekonomi.

Dalam konteks upaya meraih kebahagiaan, Mulyadi Kartanegara menyatakan bahwa Orang baik adalah orang yang sehat mentalnya, dan orang yang sehat mentalnya akan dapat merasakan kebahagiaan-kebahagiaan ruhani. Sebaliknya apabila jiwa tidak sehat, misalnya karena ada penyakit dengki, maka manusia tidak akan dapat merasakan kebahagiaan. Bahkan ia akan merasa tidak berbahagia manakala ada orang lain yang merasakan kebahagiaan. ${ }^{45}$ Di sini bahkan Mulyadi menunjukkan bahwa tindakan moral dan tindakan rasional adalah proses atau tahapan yang harus dilalui seseorang untuk meraih kebahagian.

Kesatuan antara tindakan moral dan rasional dalam ekonomi dalam Islam terefleksikan dalam wujud perbuatan-perbuatan yang baik (al-akbla $>q$ al-kari $>$ mah). Dalam hal ini Fakhr ad-Di>n ar-Ra>zi $>$ memberi contoh tentang tindakan ekonomi yang baik.Tindakan ekonomi yang baik adalah tindakan yang tidak berlebihan atau kewajaran. Dengan kata lain, dalam pandangan ar-Ra $>$ zi $>$, kebahagiaan seseorang hanya dapat diraih jika dirinya mampu secara rasional melakukan tindakan ekonomi yang wajar atau tidak berlebihan, disebut dengan kewajaran rasional. ${ }^{46}$ Konsekuensi dari kewajaran ini, seluruh kegiatan ekonomi, baik produksi, distribusi maupun konsumsi, seseorang harus mampu membuat perhitungan yang cermat agar masih dalam batas-batas yang wajar.

Terkait dengan tindakan yang harus dihindari karena dianggap buruk secara rasional dan moral, ar-Ra>zi mencontohkan dengan sikap kikir dan dusta. Meskipun ar-Ra $>$ zi tetap mengakui dusta sebagai perbuatan buruk, tetapi ia melihat nilai dusta tergantung pada niatnya. Dusta merupakan perilaku yang tercela bila bertujuan untuk kejahatan, sebaliknya dusta menjadi terpuji bila diniatkan demi kebaikan dan kemaslahatan.Begitu pula dengan sifat kikir, menurutnya tidak dapat ditolak sepenuhnya karena nilainya tergantung pada alasan melakukannya. Kikir merupakan

\footnotetext{
${ }^{45}$ Kartanegara, "Membangun”, 6.

${ }^{46}$ Mustain, Etika, 197.
} 
Konsep Rasionalitas Islami dan Implikasinya ...

sifat buruk bila dilakukan untuk kesenangan semata, sebaliknya kikir menjadi tidak buruk bila dilakukan karena dorongan perasaan takut dan khawatir akan tertimpa kemiskinan dan masa depan yang buruk. ${ }^{47}$

Memasukkan kikir dan dusta sebagai tindakan yang buruk juga sejalan dengan penjelasan ekonomi. Perbuatan kikir dapat dilihat sebagai keputusan menekan konsumsi secara radikal sehingga kebutuhan dasar seseorang tidak terpenuhi. Dalam hal ini, ilmu ekonomi menjelaskan bahwa batas konsumsi maksimum seseorang terletak pada garis anggaran (budget line) yang dia miliki. Garis anggaran ini tidak harus dipenuhi karena pelaku ekonomi harus mampu membuat pilihan-pilihan (preferensi) di antara berbagai kebutuhan dan kombinasi kebutuhan saat sekarang dan masa mendatang. Sedangkan berdusta jika diterapkan dalam kasus ekonomi dapat dianggap sebagai distorsi. Secara teknis distorsi dapat dipilah-pilah menjadi distorsi harga, distorsi kualitas maupun kuantitas.

Distorsi harga terjadi dalam kasus jual beli, yakni jika seseorang melakukan manipulasi harga sehingga berada di bawah harga wajar (harga pasar) atau di atasnya. Sedangkan distorsi kuantitas dan kualitas terjadi ketika dalam kasus jual beli, atau produksi barang dan jasa seseorang menyampaikan informasi yang tidak benar kepada pihak lain (konsumen) dengan motif mendapat keuntungan yang lebih tinggi. Distorsidistorsi ini sekilas akan menghasilkan keuntungan materi, namun tidak dapat mendatangkan kebahagiaan yang menjadi tujuan utama hidup manusia, termasuk dalam kasus ekonomi.

Dengan perspektif yang agak berbeda, Ibn Miskawaih membedakan konsep kebahagiaan (as-sa'a $>$ dah) dengan kebaikan (al-khair). Dalam hal konsep kebaikan, ia mengadopsi pendapat Aristoteles tentang kebaikan mutlak. ${ }^{48}$ Sedangkan tentang kebahagiaan, dalam pandangannya tercakup dua aspek; teoretis dan praktis. Aspek teoretis kebahagiaan bersumber dari kemauan seseorang untuk selalu berfikir tentang hakikat wujud. Sedangkan aspek praktis bersumber dari keutamaan jiwa yang akan menghasilkan perbuatan baik. Dalam proses meraih kebahagiaan, manusia harus berpegang pada syari'at sebagai pedomannya. ${ }^{49}$ Pembedaan Ibn Miskawaih terhadap kebahagiaan menjadi teoretis dan praktis ini lebih luas daripada pandangan al-Ghazali

\footnotetext{
${ }^{47}$ Ibid.

${ }^{48}$ Ibn Miskawaih, Menuju Kesempurnaan Akhlak, terj. Helmi Hidayat, Cet. Ke-2 (Mizan, Bandung, ${ }^{49}$ Ibid.
} 1994), 56. 
di atas, dimana dengan kebahagiaan teoretis orang dituntut untuk bersedia berkontemplasi memaknai realitas.

Kemampuan memaknai realitas berbeda dengan kemampuan melakukan perhitungan-perhitungan akurat dalam ekonomi karena dalam perhitungan tersebut mengandung maksud prediktif tentang apa yang mungkin terjadi dalam hukum kausalitas, sementara memaknai realitas adalah cara pandang terhadap substansi di balik realitas. Secara operasional ia merupakan kemampuan analisis yang mendalam terhadap fenomena-fenomena sehingga bersifat konseptual dan makro. Mengikuti penjelasan demikian, maka kebahagiaan dalam ekonomi dapat diraih hanya oleh mereka yang menguasai teorema-teorema ekonomi sehingga mampu menjelaskan setiap kejaidian sehingga mampu menemukan solusi atas permasalahan.Sedangkan kebahagiaan praktis memiliki dimensi mikro yang dalam penerapannya ditujukan pada kemampuan seseoang mengendalikan tindakan ekonomi dirinya sendiri, sehingga tujuan-tujuan ekonominya dapat direalisasikan.

Kemampuan orang dalam merealisasikan kebahagiaan praktis Ibn Miskawaih inilah yang dia sebut dengan $a k b l a>q$, yaitu suatu kualifikasi spiritual yang menyebabkan timbulnya perbuatan tanpa melalui pertimbangan dan dipikirkan secara mendalam. Dengan spontanitasnya tersebut, akhlaq dapat dibentuk melalui latihan dan pembiasaan agar menjadi akhlaq yang baik. Akan tetapi akhlaq berpotensi mengalami perubahan atau pembelokan, sehingga diperlukan seperangkat aturan berupa syari'at, nasehat, atau ajaran tradisi yang berhubungan dengan sopan santun. Konsep kebahagiaan praktis ini sejalan dengan pembagiannya terhadap jiwa manusia yang terdiri atas tiga tingkatan, yaitu nafsu kebinatangan, nafsu binatang buas dan jiwa yang cerdas. Perkembangan atau perubahan jiwa dan akhlaq manusia ini bersifat evolutif. Secara naluriah sejak masa kanak-kanak seseorang berusaha menghilangkan "jiwa kebinatangan” agar muncul "jiwa kemanusiaan" dan "jiwa manusia berakalnya". ${ }^{50}$

Pada saat tindakan-tindakan moral dalam ekonomi di atas hanya didasarkan pada keputusan agama untuk memerintahkan atau melarangnya, maka dalam pandangan George F. Hourani, tindakan tersebut dikategorikan ke dalam etika voluntasis (ethical voluntarist), ${ }^{1}$ dalam artian bahwa tindakan seseorang hanya dikendalikan oleh motif kesediaan melaksanakan tuntunan dan perintah agama saja. Patut diduga bahwa pandangan Hourani terpengaruh oleh filsafat pragmatisme yang menyatakan bahwa

\section{${ }^{50}$ Ibid.}

${ }^{51}$ George F. Hourani, "Ethical Presupposition of the Qur'an" dalam Muslim World, Vol. LXX, Januari 1980, 28. 
Konsep Rasionalitas Islami dan Implikasinya ...

tindakan tertentu, termasuk dalam ekonomi, tidak dapat dilepaskan dari dua hal penting, yakni ide atau keyakinan yang mendasari keputusan untuk melakukan tindakan itu sendiri dan tujuan dari tindakan. Tujuan yang dimaksud di sini adalah konsekuensi praktis atau hasil dari tindakan yang dilakukan. Lebih kongkretnya, konsekuensi yang dimaksud adalah kegunaan praktis. Dalam pandangan William James (1842-1910), salah satu tokoh Pragmatism, suatu keputusan dan tindakan dikatakan benar jika secara praktis dapat digunakan atau bermanfaat. Kriteria benar tidaknya tindakan ekonomi dengan demikian dapat dinilai apakah ia memberikan manfaat kepada si pelaku ataukah tidak. $^{52}$

Akan tetapi sebagaimana dijelaskan di atas, baik al-Ghazali, ar-Ra $>z i>$ maupun Ibnu Miskawaih dan tokoh etika Islam pada umumnya memberikan peran signifikan kepada rasionalitas dalam mengetahui perintah dan larangan tersebut. Hal ini tidak seperti yang dituduhkan oleh Musta'in bahwa dengan pandangan demikian wilayah rasional (explanation) akan terabaikan dan tidak memerlukan penjelasan lebih jauh lagi. ${ }^{53} \mathrm{Jikapun}$ al-Ghazali menekankan pentingnya pedoman moral dari agama, hal itu tidak lain untuk menghindarkan seseorang dari kemungkinan tersesat. Sebab, pertimbangan rasionalitas semata dalam memutuskan tindakan ekonomi bersifat relatif. Pengabaian peran moral agama akan menjatuhkan seseorang pada logika ekonomi konvensonal yang bersifat positivistik. Dalam pandangan "moral lama" (The Ancient Virtue Ethics) ${ }^{54}$, yang menjadi fokus utamanya adalah bagaimana meletakkan pondasi yang kokoh bagi individu-idnividu dan memberikan penjelasan tentang tindakan apa yang seharusnya dipilih, khususnya dalam ekonomi. Gagasannya tidak ditumpangi oleh kepentingan untuk merumuskan aturan-aturan baku bagi tindakan individu atau kelompok..$^{55}$

d. Hambatan pada Tindakan Ekonomi

Seperti telah dijelaskan sebelumnya, studi ekonomi memandang tindakan ekonomi dibatasi oleh dua garis yang saling berpotongan yaitu selera dan kelangkaan sumberdaya (dalam ilmu ekonomi dikenal dengan garis penawaran dan permintaan). Konsekuensi dari cara pandang studi ekonomi dalam menempatkan tindakan ekonomi secara terisolir adalah anggapan bahwa faktor yang menghambat tindakan ekonomi juga

52 Setia Budhi Wilardjo, "Aliran-aliran dalam Filsafat Ilmu Berkait dengan Ekonomi", www.jurnal.unimus.ac.id, 11.

${ }^{53}$ Mustain, "Etika", 198.

${ }^{54}$ Ryan Patrik Hanley, Adam Smith, 62-91.

${ }^{55}$ Ibid., 79-80. 
terletak pada kesulitan-kesulitan dalam mencari titik temu antara selera dan kelangkaan sumber daya tersebut.

Berbeda dengan studi ekonomi, sosiologi memandang tindakan ekonomi selalu melibatkan kerjasama, kepercayaan dan jaringan. ${ }^{56}$ Karena itu faktor -faktor yang dapat merusak kerjasama (seperti pola hubungan patron-klien), kepercayaan dan jaringan (seperti perselisihan) adalah hal-hal yang dapat menghambat tindakan ekonomi. ${ }^{57}$ Dalam perspektif sosiologi pranata struktur ekonomi dipengaruhi oleh beberapa faktor, yaitu; (1) Gathering, yaitu kegiatan atau proses pengumpulan barang atau sumber daya alam dari lingkungan. Jenis dan kuantitas barang yang dikumpulkan secara tidak langsung mencerminkan tingkat kemajuan teknologi, tingkat modal, sifat tenaga kerja dan kemampuan masyarakat mengorganisir elemen-elemen tersebut. (2) Production, yaitu kegiatan atau proses mengubah sumber daya alam menjadi barang-barang atau komditas tertentu sehingga dapat digunakan oleh subsistem lainnya. (3) Distribution, yaitu kegiatan atau proses pembagian barang dan komoditas kepada subsistemsubsistem lainnya. (4) Servicing, yaitu organisasi dari elemen-elemen yang tidak tercakup dalam proses produksi, tetapi diperlukan untuk menunjang proses ekonomi lainnya. ${ }^{58}$

Di sini pandangan ekonomi Islam menemukan kesamaan dengan sosiologi ekonomi. Akan tetapi perlu digarisbawahi bahwa variabel yang disematkan ekonomi Islam terhadap setiap faktor penghambat kerjasama, kepercayaan dan jaringan memasukkan unsur etika. Artinya bahwa keberhasilan tindakan ekonomi sangat ditentukan oleh bagaimana aktor menempatkan dimensi etis dalam merawat kerjasama, kepercayaan, dan jaringan yang dibangun dalam rangka pencapaian tujuan ekonominya, sehingga aktor harus bisa menerapkan apa yang disebut dengan perilaku etis.

Dalam pandangan Arens dan Loebbecke sebagaimana dikutip Damsar dan Indrayani, ${ }^{59}$ ada dua faktor utama yang dapat menjadi penghalang perilaku etis, yaitu: (a) standar etika yang berbeda dengan pandangan umum masyarakat; (b) adanya kehendak sendiri yang secara sadar melakukan tindakan tidak etis. Faktor yang kedua ini biasanya didorong oleh motif memperoleh keuntungan pribadi. Terkadang, seseorang yang melakukan tindakan tidak etis mencari sandaran kebenaran atas tindakannya melalui proses rasionalisasi. Rasionalisasi di sini berupa salah satu dari tiga

${ }^{56}$ Damsar dan Indrayani, Pengantar, 45.

${ }^{57}$ Ibid., $45-46$

${ }^{58}$ Narwoko dan Suyanto (eds.), Sosiologi, Teks Pengantar dan Terapan, cet. 7 (Jakarta: Prenada Media Group, 2014), 289.

${ }^{59}$ Damsar dan Indrayani, Pengantar, 46 
alasan berikut, atau bahkan gabungan dari ketiganya, yakni: pertama, semua orang melakukan hal (tindakan tidak etis) yang sama; kedua, jika suatu tindakan tidak melanggar hukum atau aturan, hal itu berarti dapat dipahami juga tidak melanggar prinsip-prinsip etis; ketiga, kemungkinan bahwa tindakan tidak etis yang dilakukan tidak diketahui orang lain sehingga dapat terbebas dari tanggungjawab.

Sebaliknya dalam analisis ilmu ekonomi, faktor-faktor yang mempengaruhi munculnya perilaku atau tindakan etis terdiri atas pengaruh budaya organisasi, kondisi politik, serta perekonomian global dimana dia hidup. Budaya organisasi adalah nilai kongkret yang disepakati bersama dalam sebuah lingkungan (perusahaan, lembaga) untuk dijadikan sebagai pedoman berperilaku orang-orang yang terlibat di dalamnya. Sedangkan politik diartikan sebagai serangkaian prisip, keadaan dan cara atau alat yang digunakan untuk mencapai tujuan bersama. Pencapaian tujuan tersebut ditentukan oleh perilaku individu-individu yang tercakup dalam suatu organisasi atau kelompok dalam memenuhi hak dan kewajibannya. Adapun yang dimaksud dengan perekonomian global adalah perilaku atau tindakan manusia dalam memenuhi kebutuhannya menggunakan sumber daya yang tersedia melalui pilihan-pilihankegiatan produksi, distribusi dan konsumsi. Dalam konteks ekonomi Islam, nilai kongkret yang dimaksud adalah etika yang digali dari ajaran Islam, baik itu yang bersumber dari al-Qur'an dan as-sunnah, maupun dari sumber-sumber lain.

Dalam pandangan al-Mawardi, tindakan ekonomi tidak seharusnya dipertentangkan dengan etika, bahkan sebaliknya keduanya merupakan kesatuan yang tidak mungkin dipisahkan. Al-Mawardi menyatakan:

"Hal terbesar yang menjadi tujuan hidup manusia adalah apa yang dapat menegakkan agama dan dunia serta dapat mengantarkan pada kebaikan akhirat dan dunia. Hal itu dikarenakan dengan tegaknya agama ibadah menjadi sah dan dengan kebaikan dunia kebahagiaan menjadi sempurna." ${ }^{\circ 0}$

Pernyataan di atas cukup eksplisit menunjukkan pandangan etis dalam Islam tentang keselarasan antara etika, dalam hal ini ajaran agama, dengan tindakan-tindakan ekonomi. Jika demikian, apa yang menjadi penghalang dalam tindakan ekonomi? AlMawardi menjelaskan sebagai berikut:

"Adapun hawa nafsu (al-hawa $>$ ) selalu melenceng dari kebaikan, bertentangan dengan rasionalitas.Hal it dikarenakan hawa nafsu muncu dari perilaku $(a k b l a>q)$ yang buruk dan perbuatan jahat yang dapat menghalangi integritas (al-muru>'ab) serta menghantarkan pada keburukan." ${ }^{1}$

${ }^{60} \mathrm{Al}-\mathrm{Ma}>$ wardi $>, A d a>b, 5$.

${ }^{61}$ Ibid, 23. 
Dalam pernyataan di atas al-Mawardi menegaskan, penghalang tindakan aktor dalam ekonomi adalah perilaku tidak rasional, yaitu perilaku yang didasarkan pada nafsu. Jika dikaitkan dengan pernyataan sebelumnya dapat disimpulkan bahwa perilaku yang menyimpang dari aturan agama dapat dikatakan sebagai penghalang dalam tindakan ekonomi. Dikatakan demikian karena perilaku menyimpang tersebut dapat menimbulkan perbuatan jahat yang dalam konteks ekonomi dapat disebut sebagai distorsi sebagai tidak berjalannya mekanisme ekonomi secara adil, serta dapat menurunkan integritas sebagai aktor.

Sebagai konsekuensinya, al-Ma>wardi menegaskan bahwa penghalang dalam tindakan ekonomi harus dihilangkan. Dalam hal ini, pihak yang memiliki kewajiban adalah penguasa. Kekuasaan dalam pandanganya memiliki tugas utama menjalankan dan meneruskan tugas kenabian dalam menjaga agama, politik dan dunia. Oleh karena itu mengangkat pemimpin yang memiliki kemampuan untuk tugas tersebut merupakan suatu kewajiban berdasarkan konsesnsus (ijma>), sebagian yang lain wajib berdasaran ketentuan syara, ${ }^{62}$ Hal ini berarti, al-Mawardi memandang perlunya intervensi pemerintah dalam mengilangkan faktor-faktor yang berpotensi menjadi penghalang tindakan ekonomi. Dengan kata lain sistem ekonomi tidak dapat berjalan secara otomatis atau diserahkan pada kebabasan individu sebagai aktor di bawah naungan hukum pasar. Pandangan al-Mawardi ini sejalan dengan mayoritas ulama tentang pentingnya intervensi pemerintah dalam ekonomi. Dalam realisainya, bentuk intervensi ini dapat dilakukan secara langsung melalui lembaga-lembaga yang dibentuk (seperti



3. Implikasi Rasionalitas Islami terhadap Studi Ekonomi Islam

a. Implikasi Paradigmatik

Sebagaimana dipaparkan di atas, Islam tidak menolak sepenuhnya konsep rasionalitas. Faktanya sebagai makhluk yang dikaruniai akal pikiran, perilaku manusia mempertimbangkan kemampuan rasionalitas untuk menentukan manfaat dan madharat perbuatannya. Hal ini sejalan dengan pandangan ilmu ekonomi yang menyatakan bahwa dalam situasi apapun selalu memperhitungkan motif untuk meningkatkan kehidupan dan kesejahteraannya atau paling tidak mempertahankan tingkat kehidupan yang tengah dinikmatinya. ${ }^{63}$

${ }^{62}$ Al-Mawardi>, al-Ah\}ka>m as-Sulta $\}>$ niyah (Semarang, Taha Puta, tt), 3-4.

${ }^{63}$ Heddy Shri Ahimsa-Putra dkk., dalam Ekonomi Moral, Rasional, dan Politik dalam Industri Kecil di Jawa; Esei-esei Antropologi Ekonomi, (Yogyakarta: KEPEL Press, 2003), 30-31 
Konsep Rasionalitas Islami dan Implikasinya ...

Meskipun demikian, nalar bukan satu-satunya pertimbangan yang mendasari tindakan seseorang. Perilaku ekonomi seseorang dan masyakat diyakini didorong oleh apa yang dipikirkan dan diyakini berupa pandangan hidup dan motivasi-motivasi moral (termasuk agama) yang dibentuk oleh sistem kepercayaan dan nilai spesifik (cultural specific belief systems and values). Kedua faktor inilah yang mengarahkan pada keputusan tentang benar dan salah dalam sistem masyarakat. Menurut perspektif ini pula manusia yang bermoral didefinisikan sebagai orang-orang beriman (the believers). ${ }^{64}$ Dengan kata lain, rasionalitas tidak bersifat independen, tetapi membutuhkan petunjuk dari sumber yang dapat dipertanggungjawabkan, yaitu petunjuk Allah. Pernyataan ini membantah klaim Neoklasik yang mengabaikan peran agama sebagai acuan utama bagi tindakan manusia. Fungsi nalar seperti yang dikemukakan oleh al-Mawardi adalah untuk memahami dan menjalankan perintah serta menjauhi larangan Allah, bukan sekedar melakukan kalkulasi untung dan rugi. Dengan konstruk nalar seperti ini, paradigma rasionalitas Islam adalah rasionalitas-relijius.

b. Implikasi pada Pembentukan Asumsi Rasionalitas Islami

Konsekuensi dari penolakan kedua basis rasionalitas Neoklasik di atas dapat diturunkan ke dalam asumsi-asumsi praktis. Rumusan al-Ghazali yang memperluas rasionalitas sehingga mencakup empat unsur; rasionalitas sebagai nalar pembeda dengan makhluk lain, rasionalitas sebagai batas kesadaran hokum (mumayyiz), rasionalitas mengakui sumber empirik, rasionalitas sebagai pengetahuan terhadap konsekuensi etis dari tindakan, berimplikasi pada perluasan asumsi rasionalitas itu sendiri. Sebagai contoh, ketika Al-Ghazali menganjurkan agar manusia menjaga keseimbangan tujuan duniawi dan ukhrawi, maka hal itu sekaligus menggugurkan asumsi Neoklasik yang menyatakan bahwa tindakan ekonomi seseorang hanya didorong oleh kebutuhan sekarang (present aim rationality). Sedangkan pernyataan alGhazali bahwa manusia harus memanfaatkal ilmu pengetahuan untuk mengetahui makanan dan minuman yang halal dan haram, sangat berpengaruh pada konsep pilihan rasional (rational choice) dan preferensi.

c. Implikasi Rasionalitas dalam Tindakan Aktor

Perluasan terahdap asumsi-asumsi rasionalitas di atas membawa implikasi praktis dalam memahami tindakan aktor. Tindakan sebuah perilaku ekonomi dikategorikan rasional tidak hanya didasarkan pada kalkulasi materiil, untung dan rugi. Lebih jauh lagi rasionalitas Islam mengukur tindakan aktor dengan memasukkan dimensi sosial dan

64 Ibid, 28-32. 
dimensi relijius. Konsekuensinya adalah, pertimbangan untung dan rugi harus ditambah dengan pertimbangan bahwa suatu tindakan harus merealisaikan mas $\}$ lab $\} a h$ dan menghindari mad $\} a>r a>t$ sebagai aktualisasi dari al-akbla $>q$ al-kari $>$ mah .

Beberapa contoh di atas memberikan gambaran yang jelas, bahwa rasionalitas islami membawa perubahan mendasar dalam pengembangan studi ekonomi Islam. Diperlukan suatu rekonstruksi ulang terhadap teori-teori ekonomi Islam yang selama ini tunduk pada asumsi-asumsi Neoklasik. Kekayaan konsep yang dikemukakan para tokoh muslim klasik menjadi bahan yang sangat berharga bagi upaya ke arah teoretisasi.

\section{Simpulan}

Dari paparan di atas dapat disimpulkan bahwa ekonomi Islam memiliki konsep rasionalitas-relijius yang khas. Kekhasan rasionalitas dalam ekonomi Islam mencakup aspek paradigmatik, rumusan asumsi-asumsi di dalamnya, serta penerapannya dalam tindakan ekonomi. Perbedaan yang sangat mendasar antara rasionalitas Islam dengan rasionalitas yang berkembang dalam ekonomi konvensional menuntut perubahan orientasi keilmuan ekonomi Islam itu sendiri. Ketergantungan penjelasan kajian ekonomi Islam selama ini terhadap rumusan rasionalitas ala Neoklasik telah membelokkan kea rah yang keliru. Hal itu terlihat dari ketertundukan mutlak kajian ekonomi Islam terhadap teori-teori dan rumus-rumus matematis ekonomi konvensional. Padahal, pemikiran para tokoh ekonomi Islam seperti al-Ghazali, Ibn Khaldun, Ibn Miskawaih dan Al-Mawardi sebagaimana dipaparkan di atas menyediakan perangkat teori yang sangat jelas. Oleh karenanya, diperlukan upaya serius untuk merekonstruksi pemikiran-pemikiran tersebut secara ilmiah untuk memberikan landasan yang kokoh bagi pengembangan ilmu ekonomi Islam.

$* * * * * * * * *$

\section{Daftar Pustaka}

Al-Gazali. M. tt. Ihya' 'Ulum ad-Din. Semarang: Nur Asia.

Nata, A. 2000. Pemikiran Para Tokoh Pendidikan Islam. Jakarta: PT. Raja Grafindo Persada.

Al-Misri, M. I. 2005. Lisan al-'Arab. (9 jilid) Cet. V. Beirut: Dar al-Qadir, Bab: 'Ain-Qaf-Lam.

Al-Mawardi. 2013. Adab ad-Dunya wa ad-Din. Beirut: Dar Kutub al-'Tlmiyah. . tt. Al-Ahkam as-Sultaniyah. Semarang: Toha Putra.

Isfandiar, A. A. 2015. Melacak Teori Rasionalitas Ekonomi Berbasis Islamic Etbics, Muqtashid Volume 6 Nomor 2.

Damsar dan Indrayani. 2013. Pengantar Sosiologi Ekonomi, ed. 2. cet. 3. Jakarta: Kencana 
Konsep Rasionalitas Islami dan Implikasinya ...

Prenadamedia Group.

Rahardjo, D. 2012. Kritik Nalar Islamisme dan Kebangkitan Islam. Jakarta: Freedom Institute.

Maharani, D., dan Hidayat, T. 2020. Rasionalitas Muslim, Perilaku Konsumsi dalam Prespektif Ekonomi Islam. Jurnal Ilmiah Ekonomi Islam Vol. 6 No. 3.

Wiranatakusuma, D. B. Dkk. 2016. Kajian Konsep Rasionalitas dan Maslahah dalam pengembangan Perbankan Syari'ah: Studi Perbandingan antara Indonesia dan Malaysia, Jurnal Ekonomi dan Studi Pembangunan Vol. 17 No. 1.

Afrina, D. 2018. Rasionalitas Muslim terhadap Perilaku Israf dalam Konsumsi Perspektif Ekonomi Islam, Ekbis, Jurnal Ekonomi dan Bisnis, Vol. 2 No. 1.

Suseno, F. M. 1987. Etika Dasar: Masalah-masalah Pokok Filsafat Moral. Yogyakarta: Kanisius.

Hourani, G. F. 1980. Ethical Presupposition of the Qur'an. Muslim World, Vol. LXX

MS., AMH; Sya'roni; Sam'ani; Marlina. 2012. Etika Bisnis Al-Ghazali dan Adam Smith dalam Perspektif Ilmu Bisnis dan Ekonomi. Jurnal Penelitian, Vol. 9 No. 1.

Miskawaih, I. 1398 H. Tahzib al-Akblaq wa Tathir al-'Araq. Beirut: Mansyurah Dar al-Maktabah al-Hayah.

Miskawaih, I. 1994. Menuju Kesempurnaan Akblak. terj. Helmi Hidayat. Cet. II. Bandung: Mizan.

Narwoko, J; Dwi; Suyanto, B. (ed.). 2014. Sosiologi, Teks Pengantar dan Terapan. cet. 7. Jakarta: Prenada Media Group

Firmansyah, M; dkk. 2012. Perdebatan Rasionalitas dalam Menjelaskan Terbentuknya ada Seleksi Pegawai Negeri. Jurnal Ekonomi dan Pembangunan Indonesia. Vol. 13 No. 1.

Ngasifudin, M. 2018. Rasionalitas dalam Ekonomi Islam. Al-Intaj. Vo.4 No. 2.

Nasution, M. E. 2009. Islamic Spirit and Morale in Economics. Jurnal of International Development and Coorperation. Vol. 15 No. 1-2.

Musta'in. 2013. Etika dan Ajaran Moral Filsafat Islam; Pemikiran Para Filosof Muslim tentang Kebahagiaan. Ulumuna: Jurnal Studi KeIslaman. Vol. 17 No. 1.

Hanley, R. P. 2009. Adam Smith and The Character of Virtue. Cambridge: Cambridge University Press.

Wilardjo, S. B. "Aliran-aliran dalam Filsafat Ilmu Berkait dengan Ekonomi", www.jurnal.unimus.ac.id, .

Sim, S. 2003. Lyotard dan Nirmanusia. terj. Ab. Sigit Djatmiko. Yogyakarta: Penerbit Jendela.

Sugiyono. 2017. Metode Penelitian Kuantitatif. Bandung: Alfabeta.

Naqvi, SNH. 1985. Etika dan Ilmu Ekonomi, Suatu Sintesis Islami. Bandung: Mizan.

an-Nabhani, T. 1997. The Economic System of Islam. ed. 4. London: Al-Khilafah Publication.

Tim Penulis Rosda. 2009. Kamus Filsafat. Bandung: Remaja Rosda Karya. 